\title{
The Dog That Did Not Bark: Why Has Sierra Leone Not Returned to War After Peacekeepers Left?
}

\author{
Adekeye Adebajo
}

\section{INTRODUCTION $^{\mathrm{I}}$}

Sierra Leone's civil war lasted from 1991 to 2000 , and resulted in an estimated 70,000 deaths and 2.6 million people displaced out of a total population of about 5.2 million at the time (about 7 million in 2020). ${ }^{2}$ The Revolutionary United Front (RUF) had invaded Sierra Leone from Liberia in March 1991 with the assistance of Charles Taylor's National Patriotic Front of Liberia (NPFL). The invasion resulted in several hundred Nigerian, Ghanaian, and Guinean troops from the Economic Community of West African States (ECOWAS) Ceasefire Monitoring Group (ECOMOG) in Liberia being deployed to assist Sierra Leone, a fellow ECOMOG member, to defend its capital of Freetown. ECOMOG's role in Sierra Leone increased tremendously after a military

\footnotetext{
A. Adebajo $(\bowtie)$

Institute for Pan-African Thought and Conversation, University of Johannesburg, Johannesburg, South Africa e-mail: aadebajo@uj.ac.za

(C) The Author(s) 2021

T. McNamee and M. Muyangwa (eds.), The State of Peacebuilding in Africa, https://doi.org/10.1007/978-3-030-46636-7_19
} 343 
coup by the Sierra Leone Army (SLA) in May 1997, which the subregional force crushed by February 1998, restoring the elected president, Ahmed Tejan Kabbah, to power. ${ }^{3}$

The United Nations (UN) Security Council established the UN Observer Mission in Sierra Leone (UNOMSIL) in July 1998, ${ }^{4}$ with only about 50 observers alongside ECOMOG's 13,000 troops (12,000 being from Nigeria). A UN peacekeeping mission in Sierra Leone (UNAMSIL) was established in October 1999 to take over from ECOMOG, with about 3,300 Nigerian peacekeepers "rehatted" as UN troops. The RUF prevented the deployment of the 17,400-strong UNAMSIL to the diamond-rich eastern provinces, and, from May 2000, attacked UN peacekeepers, killing some of them, holding about 500 of them hostage, and seizing their heavy weapons and vehicles. ${ }^{5} \mathrm{~A}$ brief British military intervention with about 800 troops helped to stabilize the situation in Freetown and its environs between May and June 2000.

The UN's disarmament program for 75,000 Sierra Leonean combatants was completed in January 2002, with 42,000 weapons collected. UN-monitored elections in May 2002 saw president Ahmed Tejan Kabbah re-elected in a landslide victory. The RUF Party (RUFP) failed to win a single seat.

The decade-long war in Sierra Leone was finally over. After six years of sometimes tortuous peacekeeping, the world body finally withdrew its remaining troops from Sierra Leone in December 2005. Though the country remained largely peaceful, many peacebuilding challenges remained unresolved. UNAMSIL had spent an estimated US \$5 billion in Sierra Leone over six years, ${ }^{6}$ but over 80 percent of these funds had gone toward its peacekeeping mission rather than for tasks such as reintegrating ex-combatants into society, reversing massive youth unemployment, restructuring a new national army, and helping to restore state institutions.

The UN Security Council established an Integrated Office in Sierra Leone (UNIOSIL) in January 2006 to coordinate international peace consolidation efforts and to support the government in Freetown. However, similar to past experiences in Liberia, Angola, and the Central African Republic (CAR), this office lacked sufficient resources and staff to assist the Sierra Leonean government effectively in its post-conflict peacebuilding and reconstruction tasks. The government in Freetown collected revenues from its diamond industry of only US \$145 million in 2005.7 Violent student and labor protests also increased, amidst widespread 
youth unemployment and weak government capacity. Instability in Côte d'Ivoire, the fragile situation in Liberia, and reports of encroachment into Sierra Leonean territory by Guinean government troops occupying disputed border areas, further threatened the country's newfound peace. ${ }^{8}$

A critical factor in Sierra Leone's stability is the complex interaction of domestic, subregional, and external actors, which is crucial to the success of conflict management and conflict prevention processes. This chapter focuses squarely on the inter-play of actors at these three interdependent levels, as these diverse players often assist or obstruct peacebuilding efforts. It sets out to solve the Sherlock Holmes-type mystery of why Sierra Leone has remained stable 15 years after peacekeepers left the country, and 20 years after the end of a devastating 11 -year civil war in which an estimated 70,000 people died.

There are estimates that suggest that in half of all conflicts, countries revert to war within five years as a result of inadequate peacebuilding. ${ }^{9}$ Considering that many of the same conditions existed in post-war Sierra Leone as existed before the war-massive youth unemployment; poor governance and corruption; regional and ethnic divisions; and 70 percent of the population living in poverty - what factors explain the reasons why Sierra Leone did not slide back into conflict? Just as in British novelist Arthur Conan Doyle's 1892 Sherlock Holmes short story, "The Adventure of Silver Blaze," this chapter asks why the dog did not bark at night.

\section{Sierra Leone’s Peacebuilding Challenges}

An estimated 42 percent of Sierra Leone's population was under the age of 15 in $2008 .{ }^{10}$ Starting with the country's major peacebuilding challenges (based on factors that usually contribute to conflicts, building on my own research on 15 conflict cases across Africa between 1956 and 2011), ${ }^{11}$ Sierra Leone's massive youth unemployment-estimated at 600,000 people by March $2010^{12}$ —was often cited as the most urgent task facing the country by both the administrations of Ahmed Tejan Kabbah (1996-2007) and Ernest Bai Koroma (2007-2018), as well as the international donor community.

Furthermore, Sierra Leone's youths were prominently involved in illegal diamond mining. Instability often erupted in mining areas involving local youths, and communities frequently claimed that they had not been consulted or compensated for the use of their land by foreign 
companies. Crimes such as armed robbery, rape, and murder continued unabated, while land disputes proliferated in local communities. It must, however, be noted that these crimes were often no worse than those in neighboring countries such as Liberia and Guinea. ${ }^{13}$

The reform of Sierra Leone's security sector-the army and the police-was also another major challenge which was again linked to the issue of youth, as a large proportion of young people were employed in this sector, even as the vast majority of demobilized youths could not find gainful employment. Both the Sierra Leone Police and Sierra Leone Armed Forces were weak institutions which had been discredited during the country's civil war: some of their members had been involved in staging the 1997 military coup, while others had joined the rebels, thus creating the "sobel" phenomenon of soldiers by day and rebels by night.

Sierra Leone's 10,500-strong armed forces faced continuing issues of low pay and low morale, exacerbated by the demobilization of staff, including 70 senior officers, by April 2006. ${ }^{14}$ The army also lacked adequate housing and the conditions in its barracks were atrocious. Further exacerbating an already difficult situation, the defense ministry and armed forces were only able to access 20 percent of their approved funds in 2007 due to cumbersome administrative processes. ${ }^{15}$ Related to reform of the security sector, was a weak justice system that lacked trained magistrates in sufficient numbers, resulting in a large backlog of cases. The country's prisons were also often in an abysmal state that compromised the rights of suspects and prisoners.

In terms of Sierra Leone's 8,900-strong police force, it suffered from a lack of equipment; corruption was widespread among its ranks; low salaries were irregularly paid; and 40 percent of its personnel had been in the force for only three years. Though many members of the senior management of the police were professional and well-trained, the middle management of the force particularly suffered from poor skills and low motivation, and one-third of its members had been employed for only three years. ${ }^{16}$ Sierra Leone's police further struggled with insufficient vehicles, communications equipment, proper accommodation, handcuffs, batons, and torches. Its financial allocation in 2007, for example, was only US $\$ 6.6$ million. ${ }^{17}$

Furthermore, deep-seated poverty presented a major challenge in efforts to reconstruct the Sierra Leonean "Humpty Dumpty." More than 60 percent of the population lived in extreme poverty, ${ }^{18}$ while 70 percent 
lived on less than US \$1 a day. ${ }^{19}$ The price of the basic staple foodrice-was also beyond the reach of most citizens. This was particularly dangerous, as "rice riots" in neighboring Liberia in April 1979 had triggered a political crisis that would eventually culminate in a decade of military rule and 13 years of civil conflict. An estimated 80-90 percent of Sierra Leone's working population were in the informal sector, ${ }^{20}$ barely surviving and struggling to eke out a living. To further compound these problems, the government had to deal respectively with cholera and Ebola outbreaks in 2012 (at least 216 fatalities) and 2014 (about 3,600 fatalities). Devastating mudslides on the outskirts of Freetown in August 2017 also killed over 1,000 people.

Infrastructure was another major challenge with erratic water and power supply. The country's road and electricity networks were dilapidated, further hampering efforts at economic recovery. This situation was exacerbated by the weakness of poorly financed District Councils (the country has 13 districts) unable to deliver social services to the populace. Despite much talk of "decentralization," most decision-making and resources still remained with the central government in Freetown, which was itself grossly under-resourced.

Poor governance, involving corrupt and unaccountable leadershipa blight on Sierra Leone since independence in April 1961-continued to be a problem across all parties. To address these multiple challenges, the UN Integrated Office in Sierra Leone-the first-ever such office established by the world body after the departure of its own peacekeepers - established five priority sectors as part of its mandate to rebuild Sierra Leone: peace and governance; human rights and rule of law; civilian police; military; and public information. Though these were clearly important areas, UNIOSIL lacked the human and financial resources to address these huge challenges: in 2006 , it had only 20 police personnel and 10 military officers, while its total civilian staff was 309 (reduced to 247 by April 2008). The mission, however, worked with other UN agencies such as the UN Development Programme (UNDP); the UN Children's Fund (UNICEF); the Office of the UN High Commissioner for Refugees (UNHCR); and the World Food Programme (WFP). Nevertheless, the UN had a mostly token presence in the country, and many of UNIOSIL's staff were limited to working in the capital of Freetown. Even after UNIOSIL was transformed into the UN Integrated Peacebuilding Office in Sierra Leone (UNIPSIL) by October 2008, this change of acronym 
scarcely made a difference to its even more limited capacity of 73 local and international staff.

In addition to these challenges, Sierra Leone also continued to face subregional challenges. It is significant to focus attention on this central problem since the country's civil war had been triggered from Liberia and assisted by the fighters of Liberian warlord, Charles Taylor. An estimated 500,000 Sierra Leonean refugees had spilled into Liberia and Guinea in the course of its civil war. Such refugee camps have traditionally been used as breeding and recruiting grounds for militias. Guinean soldiers also still occupied the border village of Yenga on the Sierra Leonean side, with reports of harassment of local villagers. Furthermore, Guinean troops were encroaching on the Kambia area in Sierra Leone, ordering a bauxite mining company to stop prospecting in $2006 .^{21}$

\section{Addressing the Peacebuilding Challenges}

Having outlined Sierra Leone's key peacebuilding challenges, the efforts of key domestic, subregional, and external actors to address these obstacles and to prevent the country's relapse into conflict are assessed below.

\section{Domestic Actors}

One crucial but often overlooked source of Sierra Leone's stability is its active civil society sector, which remained vibrant even during the worst periods of the country's civil war. These civic groups were instrumental in pressuring the military to leave power in February 1996. Sierra Leonean lawyer and a leading light in her country's civil society movement in the 1990s, Yasmin Jusu-Sheriff, traced the history of the country's civic groups to the opposition of one-party rule under Siaka Stevens between 1968 and 1985, when university students and independent media like the Tablet and For Di People led the charge against autocratic rule. She went on to note that, during the civil war of 1991-2002, women's groups (such as the Women's Movement of Sierra Leone); religious organizations (such as the Multi-Religious Council [MRC]); student activists (such as the National Union of Sierra Leone Students [NUSS]); media organizations (such as the Sierra Leone Association of Journalists [SLAJ]); trade unions (such as the Sierra Leone Labour Congress); traditional leaders (who mobilized local communities to form self-defense militias known as 
Kamajors, Gbethis, Tamaboros, and Donsos); and other civic groups, all sought to hold successive governments accountable.

In implementing the 1999 Lomé Peace Accord, the chiefs in southern Sierra Leone played a particularly instrumental role in reconciliation efforts and in reintegrating ex-combatants into local communities. During the country's May 2002 elections, the Sierra Leone Labour Congress and the Sierra Leone Association of Journalists played leading roles in voter education and election monitoring. ${ }^{22}$ After peacekeepers left Sierra Leone in 2005, these civic groups sought to promote transparent governance, human rights, press freedom, access to justice, gender equality, strengthening public institutions, and securing reparations for victims of the civil conflict, as recommended by the country's Truth and Reconciliation Commission (TRC). Other groups that form part of the country's associational life have included long-standing church groups, Islamic fraternities, reciprocal labor companies, initiation societies, rotary and other social clubs, sports clubs, and credit clubs (such as osusu, involving rotating credit). These diverse actors have demonstrated great resilience and resourcefulness in the face of the country's hardships, and provided the glue that held Sierra Leone's post-war society together. ${ }^{23}$

The country also has a plurality of voices with 28 political parties, 49 daily newspapers, and 39 radio stations by August 2006, ${ }^{24}$ though regulation of the media remained weak and ethical journalistic standards were not always observed. Sierra Leone, further, significantly produced some of the finest scholars in the Diaspora-Yusuf Bangura, Jimmy Kandeh, Ismail Rashid, Yasmin Jusu-Sheriff, Aminatta Forna, and Tunde Zack-Williams, to name a few.

One sector that successive governments in Freetown seem to have prioritized was the critical area of education, with 20 percent of expenditure going to this important area by August 2006, and primary school enrolment doubling between 2000 and 2005. ${ }^{25}$ The government also launched youth employment and empowerment schemes which, however, suffered from a lack of funding and failed to make much of a dent in the country's large youth unemployment statistics. But as Sierra Leonean scholar, Ismail Rashid, insightfully noted, while there has been widespread youth unemployment in post-war Sierra Leone, there has not been largescale youth destitution. The country's youths have been resourceful at engaging in such activities as petty trading, street-hawking, driving okada (motorbike) taxis, and engaging in other transport services. ${ }^{26}$ 
Despite its multiple challenges, successive governments in Freetown also deserve credit for leading efforts at organizing three presidential and parliamentary elections in 2007,2012 , and 2018 with two to four million voters participating in each poll. The UN provided some technical assistance to these efforts. An impressive 91 percent of eligible voters-2.6 million people-registered for the August 2007 polls, ${ }^{27}$ suggesting that the vast majority of Sierra Leoneans felt that they had a stake in building a viable democracy. The fact that many former RUF combatants voted for the All People's Congress (APC) in $2007^{28}$ also suggested that the ballot-rather than the bullet-was now seen, even by former fighters, as a viable way of changing a civilian regime.

Equally impressive was the fact that the opposition APC was able to defeat the incumbent Sierra Leone People's Party (SLPP) government which had been in power since March 1996. Despite violent clashes between supporters of both parties, as well as intimidation and harassment-particularly in the SLPP's traditional southern and eastern strongholds - the polls were successfully held, and power was peacefully transferred from Ahmed Tejan Kabbah to Ernest Bai Koroma in 2007. The 2012 polls also saw a high 87 percent of voters turning out, showing that confidence in the ballot box remained high. The fact that no ethnic group in Sierra Leone is numerically dominant means that politicians are forced, to some extent, to build coalitions that simply go beyond narrow ethnic blocs. ${ }^{29}$

Like the fabled Old Mother Hubbard, on assuming office in 2007, Ernest Koroma went to the national cupboard to find it bare. He effectively inherited an empty treasury, asking donors to fund 80 percent of the national budget on assuming office. ${ }^{30}$ The president was often quick to manage incidents of electoral conflicts, setting up commissions of inquiry to investigate serious acts of violence. Inter-party dialogues involving senior officials and youth and women's wings of the two main parties also helped to ease tensions. Koroma appeared to be more dynamic an administrator than the mild-mannered and sometimes lackadaisical Kabbah. He established a fast-track anti-corruption court, and took action-not always consistently-even against some members of his own party.

The president did manage some other achievements, particularly in the area of infrastructure, confirmed by his overwhelming re-election in November 2012. Koroma's Bumbuna Hydroelectric Project boosted the country's electricity supply. He increased government revenues through introducing a goods and services tax in 2010. He established an Office of 
Diaspora Affairs in the presidency to tap into increased remittances from the large Sierra Leonean Diaspora. He initiated free health care for pregnant women, new mothers, children and infants and advocated increased food self-sufficiency as his government's highest priority, providing more support to the country's farmers through seeds and fertilizers.

But despite these efforts, the estimated value of Sierra Leone's exports was still a measly US $\$ 180$ million in $2009 .{ }^{31}$ Koroma was accused after the 2007 election of fanning ethnic divisions by replacing large numbers of senior officials in the civil service and parastatals from the SLPP with APC-supporting northerners. ${ }^{32}$ The president's Agenda for Prosperity, which sought to transform the country's agricultural sector, was derailed by the Ebola crisis of 2014/2015, with Sierra Leone classified as the third hungriest country in the Global Hunger Index by 2017. As Koroma's term was coming to an end by March 2018, his administration was accused of embezzling funds meant for Ebola relief and siphoning funds from a scholarship program meant for poor Sierra Leoneans making the Hajj pilgrimage to Mecca. ${ }^{33}$

\section{Regional Actors}

Turning from the domestic to the subregional level, the three heads of state of the Mano River Union-Sierra Leone, Guinea, and Liberiamet regularly to discuss security issues in the volatile Mano River basin. Freetown also played an active role in subregional diplomacy through ECOWAS summits. With the arrival in power in Conakry of the democratically elected Alpha Condé, in December 2010, relations with Guinea improved dramatically. By April 2013, Guinean troops had completed their withdrawal from Yenga, an area that had been occupied since 1999. ${ }^{34}$ The stability of Sierra Leone's neighborhood after the end of conflict in Liberia in 2003 and the end of military rule in Guinea by 2010 were thus important factors in reducing incentives for Sierra Leonean youths to join rebel militias in neighboring countries.

\section{External Actors}

A plethora of international actors were involved in assisting Sierra Leone's peacebuilding efforts. Led by the UN and its agencies, these actors also included the African Development Bank (AfDB), the World Bank, the International Monetary Fund (IMF), the International Fund for 
Agricultural Development (IFAD), the European Union (EU), and the governments of Britain, the United States (U.S.), Ireland, the Netherlands, Denmark, Japan, Germany, and Canada. Though the support provided by these international donors was useful in keeping the fragile peace, the amounts provided were often derisory, and clearly insufficient for transforming Sierra Leone's institutions to ensure sustainable peace.

In 2006, for example, only US $\$ 351.5$ million-less than half of the estimated US $\$ 850$ million that the UN peacekeeping force in the country spent annually - was provided to Sierra Leone by international donors. ${ }^{35}$ The UN Peacebuilding Commission's paltry contribution of US \$35 million-which it took over three years to disburse-was particularly embarrassing for a body set up at the same time as the UN peacebuilding office in Sierra Leone. A Victim's Trust Fund established by the government in Freetown in September 2009 had attracted only US \$25,000 a year later. ${ }^{36}$ Even the UN's own Joint Vision 2009-2010 of US $\$ 360$ million had a shortfall of US \$151 million by the end of its funding period. ${ }^{37}$ The EU and the World Bank grandiosely announced a three-year "decentralized service delivery program" in 2012 worth a derisory US \$32 million. The rhetoric of external donors was always more impressive than their actual provision of resources.

Foreign assistance correctly prioritized Sierra Leone's security sector since the failure of the country's army to maintain a monopoly of legitimate armed force over its territory had facilitated the country's civil conflict in the first place. The British-led Security Sector Reform Programme (SILSEP) and its International Military Advisory and Training Team (IMATT) — which provided much security reassurance to the Sierra Leonean population ${ }^{38}$ —drove efforts to restructure and retrain the Sierra Leone army, but had only 65 staff in 2001. A year later, 2,091 fighters from diverse factions outside the army had been integrated into a 12,000-strong army. Despite this external assistance, defense spending in 2006/2007 was only US \$13.3 million, meaning that half of the programmed defense expenditure could not occur. ${ }^{39}$ These programs nevertheless eventually led to the reduction of the army's strength from 10,600 in 2006 to 8,500 by $2012 .{ }^{40}$ There were, however, reports of a lack of consultation by the British government with Freetown in drawing up army restructuring benchmarks (within a 10 -year GB $£ 40$ million annual bilateral development assistance program for Sierra Leone between 2002 and 2012). ${ }^{41}$ 
Ismail Rashid provided a balanced assessment of British efforts at restructuring the Republic of Sierra Leone Armed Forces (RSLAF), praising the renewed professionalism, discipline, and credibility of the army, but noting that London's overbearing leadership of the program had denied the government in Freetown ownership of it. Vehicles, communication equipment, arms (worth about US \$1.4 million), ${ }^{42}$ and uniforms were provided by London. New recruitment criteria, structures, and missions were also developed by British military personnel, who took over the training of the army from the former Nigerian Chief of Defense Staff (CDS) of the Sierra Leone army, General Maxwell Khobe, who died in April 2000, as the British were stepping up their presence. The Nigerian-led ECOMOG peacekeeping force in Sierra Leone had recommended that the country create a 5,000-strong army, while upgrading its navy and air force. ${ }^{43}$ London simply brushed aside these subregional plans in place of its own models. As Nigerian defense minister at the time, General Theophilus Danjuma, noted in March 2001: "The British have a very good propaganda machinery. They make a lot of noise and have succeeded in replacing us in the armed forces headquarters in Freetown, but they are doing very little elsewhere." 44

Eboe Hutchful's insightful critique of security sector reform in Sierra Leone is also worth bearing in mind. He has consistently advocated the concept of "security sector governance" in which institutions of accountability and oversight would be strengthened from the bottom up rather than from the top down. Hutchful was critical of the lack of oversight institutions in post-conflict Sierra Leone, particularly the executive and legislative sectors, and noted an initial reluctance on the part of civil society to engage the security sector due to the hostility toward soldiers engendered by the country's decade-long civil war. The Ghanaian scholar observed that in environments like Sierra Leone, security sector reform has often reflected Westphalian assumptions of the state as the sole provider of security, and thus failed to incorporate community-based justice and security systems, as well as traditional institutions such as village chiefs and secret societies, into their reforms. Hutchful further noted that President Kabbah's government did not take security sector reform seriously, and criticized London's tendency to draw on intricate British models in designing the defense ministry and the national security office, which often undermined local ownership. He also bemoaned the modest attention given to the vital justice sector. ${ }^{45}$ 
Britain further contributed to efforts to reform the 8,900-strong Sierra Leone Police (SLP) through the Justice Sector Development Programme (JSDP). A retired British assistant chief constable, Keith Biddle, was put in charge of the police force as Inspector-General between 1999 and 2003. Biddle enjoyed a particularly close relationship with President Ahmed Tejan Kabbah. ${ }^{46}$ London provided GB $£ 25$ million for restructuring Sierra Leone's police, with senior officers trained at Britain's Police Staff College in Bramshill. The force was provided with 700 vehicles, communication equipment, and uniforms. This program was later transformed into the British-dominated Commonwealth Community Safety Project between 2000 and 2005. "Local needs policing" was introduced, the force was strengthened to be able to combat domestic protests, and a Complaint, Discipline, and Investigations Department was created. By November 2006, Sierra Leone's police force had achieved its full strength of $9,500^{47}$ (up from 6,600 in 1999). But corruption still remained rife within the force, leading to questions of credibility among the general population.

One of the most widely praised projects of these police reforms was the Family Support Units (FSUs), pioneered by the most senior female police officer in the SLP, Kadi Fakondo. This innovative project saw specialized police stations established to deal with domestic violence, sexual assault, and child abandonment; as well as police officers conducting sensitization workshops with local communities, resulting in greater monitoring of gender and child-related crimes. But underlining the difficulty of sustaining these projects, funding for police reforms had practically been exhausted by $2009 .{ }^{48}$

Despite these contributions to rebuilding Sierra Leone's police sector, fundamental questions must be raised, in light of the Macpherson report of 1999-2000, which shook the British establishment to its core. The report declared-something many ethnic minorities had known for decades-that the police force in London, the country's largest, suffered from "institutionalized racism." In the decade after Macpherson, African and Asian minorities suffered 1.5 million more stop-and-searches than white Britons, resulting in London's Metropolitan Black Police Association (BPA) declaring in April 2013 that the Met was still institutionally racist. ${ }^{49}$ Given these statistics, one is forced to ask whether Britain was really in a credible position to "export" what it did not have-an impartial police force-abroad. 
Youth was another vital sector that enjoyed priority from external actors, with about 800,000 young people in Sierra Leone being unemployed, underemployed, or employed without being paid. ${ }^{50}$ The Koroma government established a National Youth Commission for implementing youth development programs, and a new ministry of Youth Employment and Sports by 2011. The World Bank launched a US \$20 million threeyear project to increase business and employment opportunities for youth through apprenticeships, business development, and other skills. These efforts were also supported by the UNDP and other donors, focusing on supporting government youth employment schemes; microfinancing skills; and work-for-cash and food-for-work projects. As impressive as these programs often sounded, many-including several World Bank projects-were attracting funding of paltry sums in 2011: a US \$10 million cash-for-work scheme and a US \$6 million employment proposal scheme. A particularly neglected area was programs for vulnerable young women in post-war Sierra Leone, with rape now a major scourge of post-war society.

In March 2014, UNIPSIL left Sierra Leone, effectively ending a 16year UN peacekeeping and peacebuilding presence in the country.

\section{CONCLUSION}

Sierra Leone held its fifth post-war election in March 2018, involving 16 political parties. Despite sporadic violence in parts of the country and a dispute over the electoral results, the polls were largely peaceful. The SLPP's former head of the ruling military junta for three months in 1996, Julius Maada Bio, won 51.8 percent of the vote in the second round to the APC's Samura Kamara's 48.2 percent. ${ }^{51}$ An impressive 2.6 million Sierra Leoneans ( 84 percent of registered voters) took part in the polls, demonstrating the continuing confidence of the vast majority of the population in the ballot, and resulting in an impressive third transfer of power in a decade between the country's two main parties. However, with such a narrow margin of victory - and with no parliamentary majorityamidst an acrimonious, ethnic-fueled election campaign, many challenges lay ahead for the new administration.

President Maada Bio's first two years in office (2018-2020) saw a continued focus on trying to revive the economy. A commission of inquiry reportedly uncovered evidence of gross corruption by the previous administration of Ernest Koroma. However, an Independent 
Commission for Peace and National Cohesion was also established, and a reconciliation meeting was held between Bio and Koroma in State House in September 2019. A high court ruling in May 2019 canceled the disputed election of 10 APC parliamentarians in polls held a year earlier, and all the seats subsequently ended up with Bio's SLPP, handing the ruling party a one-seat majority in parliament ( 58 to 57 seats). ${ }^{52}$

\section{Key ReCOMmendations}

Four key policy lessons can be drawn from this case at the domestic, subregional, and external levels for future peacebuilding efforts in Africa and elsewhere. As ever, the specific idiosyncrasies of Sierra Leone must always be kept in mind.

\section{Ensure that local actors are the authors of rebuilding their own} state, even as they rely heavily on external resources. Domestic civil society organizations and dynamic leadership have a crucial role to play in post-war stability. A strong civil society with a long tradition of holding governments accountable appears to have been important to successful post-conflict peacebuilding efforts in Sierra Leone. Dynamic leadership also appears to have made a difference under Ernest Koroma's leadership, particularly between 2007 and 2012. While the UN, the World Bank, and international donors continue to tout their "state-building" ambitions, they clearly lacked the resources and local knowledge to rebuild the Sierra Leonean state. But donor funds have not been provided to Sierra Leone in the quantities required (Marshall aid to rebuild Europe after 1945 was US $\$ 100$ billion), and the Sierra Leonean state-like an old carhas gone through an arduous process of "panel beating" rather than rebuilding. It remains fragile and in constant danger of breakdown, requiring frequent care, resourceful innovation, and close attention just to keep the battered jalopy on the road.

2. Prioritize subregional engagement and leadership. In terms of the role of subregional actors, one of the most striking observations is the central role that Nigerian-led subregional peacekeepers had played in Sierra Leone during its decade-long civil war in the 1990s in stark contrast to their almost invisible role in post-conflict peacebuilding. Representatives of Nigeria and Ghana took part in efforts to reconcile political actors, while ECOWAS pledged US \$2 
million to infrastructure projects in Sierra Leone in April 2010. ${ }^{53}$ However, neither ECOWAS nor the African Union (AU) had the substantial resources to contribute to peacebuilding efforts, and even regional hegemon Nigeria-accounting for about 70 percent of West Africa's economy-which had invested so much blood and treasure in the country, sacrificing the lives of at least 500 peacekeepers and spending billions of dollars between 1991 and 2000 , did not play a prominent role in peacebuilding efforts in Sierra Leone. Questions must surely be asked why Britain-with very limited peacekeeping experience-should have been training the Sierra Leone army, when Nigeria and Ghana had five decades of international peacekeeping experience, had collaborated with the Sierra Leone army under ECOMOG in Liberia for nearly a decade, and were closer to the country's military in terms of culture and equipment needs.

3. Enhance scrutiny and accountability of external peacebuilding actors. The role of external peacebuilding actors also requires critical scrutiny to which they have rarely been exposed. UN agencies, the World Bank, and other international donors have frequently painted a rosy, but exaggerated picture of the great impact that their projects have had in transforming postwar Sierra Leone, in order to continue attracting donor funding. The world body's greatest asset is undoubtedly the legitimacy that it lends to international efforts and its mobilizing abilities, ensuring that the powerful 15 -member UN Security Council continues to focus attention on countries like Sierra Leone. International donors in Sierra Leone, however, often lacked proper coordination, and some planted their flags on different bilateral projects touting apparently impactful contributions that were just a drop in a much larger ocean of need. There was also sometimes a patronizing and paternalistic feeling that outsiders knew best, and many donors thus, at times, ignored Sierra Leonean government or civil society priorities, leading to charges of "donor democracy."

Britain clearly sought to act as a lead nation in promoting security sector reform in a former West African colony-maintaining a similar hyperactivity as France has done in former colonies such as Mali, Côte d'Ivoire, and Chad-to justify a veto-wielding permanent seat on a UN Security Council that has long become anachronistic. As 
with the Gallic role in its former colonies, there was also a commercial side to London's role in Sierra Leone: British company, London Mining, and African Minerals Limited won a major contract in 2010 to develop iron ore deposits in Sierra Leone, while British firms disproportionately benefitted from security sector reform contracts. This was, therefore, not merely a case of charitable benevolence by a neo-colonial Santa Claus.

4. Support Sierra Leoneans' efforts to move from stabilization to transformation of their still fragile state. Despite the messy complexities of Sierra Leone's post-conflict peacebuilding process, the mystery of why the dog did not bark, and why Sierra Leone has not relapsed into conflict in two decades since 2002 after a devastating 11 -year conflict, lies in the actions of these domestic, subregional, and external actors who somehow "muddled through" and improvised one of the few relative peacebuilding success stories of the last two decades. For this case to remain a sustainable success, however, serious resources will need to be provided by regional and external donors to enable domestic actors in Sierra Leone to truly transform their society.

Acknowledgements The author wishes to thank Yusuf Bangura, John Hirsch, David Keen, Ismail Rashid, and the editor, Terence McNamee, for very useful comments on an earlier version of this chapter.

\section{Notes}

1. This introduction draws from Adekeye Adebajo, "The Tragic Triplets: The UN in West Africa," in Adekeye Adebajo, UN Peacekeeping in Africa: From the Suez Crisis to the Sudan Conflicts (Boulder and London: Lynne Rienner, 2011), 148-152.

2. Mary Kaldor with James Vincent, "Evaluation of UNDP Assistance To Conflict-Affected Countries: Case Study Of Sierra Leone," UNDP Evaluation Office (New York, 2006), http://web.undp.org/evaluation/doc uments/thematic/conflict/SierraLeone.pdf.

3. For background to the Sierra Leone conflict, see Ibrahim Abdullah and Patrick Muana, "The Revolutionary United Front of Sierra Leone: A Revolt of the Lumpenproletariat," in African Guerrillas, Christopher Clapham (ed.) (Oxford: James Currey, 1998), 172-193; Adekeye Adebajo, Building Peace in West Africa: Liberia, Sierra Leone and GuineaBissau (Boulder: Lynne Rienner, 2002); African Development 22, no. 2 
and 3, special issue on "Youth Culture and Political Violence: The Sierra Leone Civil War" (1997); John Hirsch, Sierra Leone: Diamonds and the Struggle for Democracy (Boulder: Lynne Rienner, 2001); David Keen, Conflict and Collusion in Sierra Leone (Oxford: James Currey, 2005); and 'Funmi Olonisakin, Peacekeeping in Sierra Leone: The Story of UNAMSIL (Boulder and London: Lynne Rienner, 2008).

4. United Nations Security Council, Resolution 1181 (1998), S/RES/1181 (1998), July 13, 1998.

5. United Nations Security Council, Third Report of the UN SecretaryGeneral on the UN Mission in Sierra Leone, S/2000/186, March 7, 2000, 3-4; and United Nations Security Council, Fifth Report of the UN Secretary-General on the UN Mission in Sierra Leone, S/2000/751, July $31,2000,4$.

6. Personal discussions with senior UN officials, New York, February 2006.

7. United Nations Security Council, Twenty-sixth Report of the UN Secretary-General on the UN Mission in Sierra Leone, S/2005/596, September 20, 2005; and United Nations Security Council, Fourth Report of the Secretary-General on the United Nations Integrated Office in Sierra Leone. S/2010/135, March 15, 2010, 12.

8. United Nations Security Council, First Report of the Secretary-General on the United Nations Integrated Office in Sierra Leone. S/2006/269, April 28, 2006, 2-3.

9. Olonisakin, Peacekeeping in Sierra Leone, 125-126.

10. International Crisis Group, "Sierra Leone: A New Era of Reform?," Africa Report no. 143 (July 31, 2008): 22.

11. Adebajo, UN Peacekeeping in Africa.

12. UNSC, Fourth Report of the Secretary-General, 12.

13. Kieran Mitton, "Where Is the War? Explaining Peace in Sierra Leone," International Peacekeeping 20, no. 3 (November 2013): 323.

14. UNSC, First Report of the Secretary-General, 5.

15. International Crisis Group, "Sierra Leone: A New Era Of Reform?," 19.

16. UNSC, First Report of the Secretary-General, 4-5.

17. UNSC, Fifth Report of the Secretary-General, 4.

18. UNSC, First Report of the Secretary-General, 11.

19. UNSC, Fourth Report of the Secretary-General, 8.

20. UNSC, Third Report of the Secretary-General, 10.

21. UNSC, First Report of the Secretary-General, 3-4.

22. The above two paragraphs are summarized from Yasmin Jusu-Sheriff, "Civil Society," in West Africa's Security Challenges: Building Peace in a Troubled Region, Adekeye Adebajo and Ismail Rashid (eds.) (Boulder and London: Lynne Rienner, 2004), 272-275.

23. International Crisis Group, "Sierra Leone: A New Era of Reform?," 6 and 24. 
24. United Nations Security Council, Second Report of the Secretary-General on the United Nations Integrated Office in Sierra Leone, S/2006/695, August 29, 2006, 2.

25. UNSC, Fourth Report of the Secretary-General, 1.

26. Personal correspondence with Ismail Rashid, 11 September 2017.

27. UNSC, Second Report of the Secretary-General.

28. Mitton, "Where Is The War? Explaining Peace In Sierra Leone," 327.

29. Personal correspondence with Ismail Rashid, 11 September 2017.

30. UNSC, Fifth Report of the Secretary-General, 13.

31. UNSC, Third Report of the Secretary-General, 3.

32. International Crisis Group, "Sierra Leone: A New Era Of Reform?," 11.

33. I thank Yusuf Bangura for these points cited in an unpublished short paper. Yusuf Bangura, "Why We Need Change: The Case for A Developmental, Inclusive and Democratic Party" (Unpublished manuscript, November 12, 2017).

34. United Nations Security Council, Eleventh Report of the SecretaryGeneral on the United Nations Integrated Peacebuilding Office in Sierra Leone, S/2013/547, September 12, 2013, 1 and 12.

35. UNSC, Fourth Report of the Secretary-General, 8.

36. UNSC, Fifth Report of the Secretary-General, 9.

37. United Nations Security Council, Sixth Report of the Secretary-General on the United Nations Integrated Peacebuilding Office in Sierra Leone, S/2011/119, March 9, 2011, 10.

38. I thank Terence McNamee for this insight, based on time spent with the British international training mission in Freetown in 2007.

39. Peter Albrecht and Paul Jackson, "II. 1997-2007: The Evolution of Security-Sector Reform in Sierra Leone," Whitehall Papers 82, no. 1 (2014): 29 and 34.

40. See Albrecht and Jackson, "II. 1997-2007"; Osman Gbla, "Security Sector Reform Under International Tutelage in Sierra Leone," International Peacekeeping 13, no. 1 (2006): 78-93; and Lisa Denney, "Explaining War, Creating Peace: UK-Sponsored Reforms in Sierra Leone," in Contemporary Review 291, no. 1693 (2009): 153-161.

41. Comfort Ero, "Peacebuilding Through Statebuilding in West Africa? The Cases of Sierra Leone and Liberia," (2012), 241.

42. Albrecht and Jackson, “II. 1997-2007," 42.

43. Gbla, "Security Sector Reform Under International Tutelage," 83.

44. Personal Interview with General Theophilus Danjuma, defense minister of Nigeria, Abuja, 2 March 2001.

45. Eboe Hutchful, "Security Sector Governance and Peacebuilding," in Peacebuilding, Power, and Politics in Africa, Devon Curtis and Gwinyayi A. Dzinesa (eds.) (Athens: Ohio University Press, 2012), 63-86. 
46. Albrecht and Jackson, "II. 1997-2007," 40-41.

47. UNSC, Third Report of the Secretary-General, 4.

48. Denney, "Explaining War, Creating Peace," 158-160.

49. See, for example, Vikram Dodd, "Minorities Stopped Disproportionally In Decade After Macpherson Report," The Guardian, April 22, 2013, https://www.theguardian.com/law/2013/apr/22/ethnic-min ority-britons-stop-search-white; and Hugh Muir, "Metropolitan Police Still Institutionally Racist, Say Black and Asian Officers," The Guardian, April 21, 2013, https://www.theguardian.com/uk/2013/apr/21/met ropolitan-police-institutionally-racist-black.

50. UNSC, Fifth Report of the Secretary-General, 12.

51. See, for example, Jaime Yaya Barry, "Sierra Leone's Opposition Leader Is Sworn in as President," The New York Times, April 4, 2018, https://www. nytimes.com/2018/04/04/world/africa/sierra-leone-president.html.

52. "Sierra Leone: Back to School," The Africa Report no. 110 (JanuaryMarch 2020): 228.

53. UNSC, Fifth Report of the Secretary-General, 11.

Open Access This chapter is licensed under the terms of the Creative Commons Attribution 4.0 International License (http://creativecommons.org/licenses/ by $/ 4.0 /)$, which permits use, sharing, adaptation, distribution and reproduction in any medium or format, as long as you give appropriate credit to the original author(s) and the source, provide a link to the Creative Commons license and indicate if changes were made.

The images or other third party material in this chapter are included in the chapter's Creative Commons license, unless indicated otherwise in a credit line to the material. If material is not included in the chapter's Creative Commons license and your intended use is not permitted by statutory regulation or exceeds the permitted use, you will need to obtain permission directly from the copyright holder.

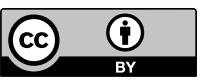

